ISSN 1392-3196 / e-ISSN 2335-8947

Zemdirbyste-Agriculture, vol. 102, No. 2 (2015), p. 133-140

DOI 10.13080/z-a.2015.102.017

\title{
Nitrogen apparent recovery can be used as the indicator of soil nitrogen supply
}

\author{
Aldis KARKLINS, Antons RUZA \\ Latvia University of Agriculture \\ 2 Liela, Jelgava, 3001 Latvia \\ E-mail: aldis.karklins@1lu.lv
}

\begin{abstract}
The Nitrates Directive requires considering all possible sources of nitrogen available for crops before decision is made for the use of commercial fertilisers. Soil is one of the nitrogen supplying sources but to quantify the amounts which could be released in a plant available form and take part in yield formation is difficult. Chemical and biological methods developed for laboratory and field conditions do not always give good response or are unpractical for farm conditions. Therefore an indirect soil nitrogen supply assessment method is proposed which could use the data available for each field on every farm. The first step includes estimation of soil total organic nitrogen pool derived from indices of soil organic matter content and soil $\mathrm{pH}$. The second step is the use of soil nitrogen apparent recovery factors, developed from field experiment data. Such factors were developed for winter rye and wheat, spring wheat and barley, winter and spring rape as well as potatoes and are based on 72 field experiments performed in Latvia on mineral soils within a five-year (2008-2012) period. In average, the following soil nitrogen recovery factors were obtained: for winter cereals $-3.3-3.4 \%$, winter rape $-2.3 \%$, spring cereals and rape $-1.8-2.6 \%$ and potatoes $-3.8 \%$, calculated from the soil total organic nitrogen pool within $0-20 \mathrm{~cm}$ depth. There was strong correlation $(r=0.980, P \leq 0.01)$ between apparent recovery values if they were calculated only based on $0-20 \mathrm{~cm}$ soil layer or based on $0-40 \mathrm{~cm}$. Therefore it is possible to make calculations only for topsoil data which are commonly available from routine soil tests.
\end{abstract}

Key words: fertiliser recommendations, soil mineral nitrogen, soil nitrogen supply, soil organic matter.

\section{Introduction}

Nitrogen is among the plant nutrients whose use has been strictly regulated. On the one hand, no organism is able to develop without nitrogen and its requirement directly corresponds to plant growth intensity and as a result-crop productivity. On the other hand, any surplus of nitrogen can negatively affect crop growth but especially - environmental quality. Therefore besides agronomic considerations, several administrative limitations are set up dealing with nitrogen use. Stricter regulations are valid for farms, located in the so-called vulnerable zones - area of land in their territories which drains into the waters and might discharge, directly or indirectly nitrogen compounds from agricultural sources into the aquatic environment, the results of which are such as to cause hazards to human health, harm to living resources and to aquatic ecosystems, damage to amenities or interference with other legitimate uses of water (Council Directive 91/676/EE; Directive 2000/60/EC).

Several mandatory measures are set up for land application of nitrogen fertilisers in particular for determination of rate and timing of fertiliser use. One of them is assessment of nitrogen supply through the net mineralization of the reserves of organic nitrogen in the soil. Within the context of Nitrates Directive and all other measures provided for in this document, it means assessment of the so-called soil nitrogen supply (SNS). It could be defined as the amount of nitrogen $\left(\mathrm{kg} \mathrm{ha}^{-1} \mathrm{~N}\right)$ in the soil (apart from that applied for the crop in manufactured fertilisers and manures) that is available for uptake by the crop throughout its entire life, taking account of nitrogen losses (Fertiliser Manual, 2010). According to this definition, SNS could be calculated as:

$$
\mathrm{SNS}=\mathrm{N}_{\text {min }}+\mathrm{N}_{\text {crop }}+\mathrm{N}_{\mathrm{OM}}
$$

where $\mathrm{N}_{\min }$ is soil mineral nitrogen $\left(\mathrm{N}-\mathrm{NH}_{3}+\right.$ $\mathrm{N}-\mathrm{NO}_{3}$ ) in crop rooting zone, $\mathrm{N}_{\text {crop }}$ - nitrogen content in crop (if present) at the moment of SNS estimation, $\mathrm{N}_{\mathrm{OM}}$ - net mineralizable nitrogen, originated from organic matter.

Using this approach, net mineralizable nitrogen $\left(\mathrm{kg} \mathrm{ha}^{-1} \mathrm{~N}\right)$ is the amount of nitrogen which could be available for crop uptake from mineralization of soil organic matter and crop debris during the growing season. After crop establishment it is a potentially important source of nitrogen for plant uptake. If this value could be easily obtained for every field located within the vulnerable zones, requirements of Nitrates Directive will be fulfilled.

The mineralization of soil organic matter and release of nitrogen can be measured in a laboratory by microbiological or chemical methods. However, some 
authors point out that close agreement between these experiments and field measurements is mostly lacking (Hofman et al., 1985; Sharifi et al., 2007; Ros, 2011). For example, research done with potatoes showed that nitrogen recommendations based on soil analysis were no better than those based on the information of previous cropping and soil type (Zebarth et al., 2005). Therefore the authors of the United Kingdom fertiliser recommendation guide suggest that, since research has not yet identified a preferred laboratory method that is suitable for routine use, measurement of the topsoil organic matter content and computer modelling could give more useful indications (Fertiliser Manual, 2010).

Going back to other nitrogen sources in the soil, let us look at other parameters under consideration. The rest of the two components presented in the $1^{\text {st }}$ equation correspond to the additional sources of nitrogen potentially available or already uptaken by crops and showing the whole source of the nitrogen supply to the crops from the soil. The first component corresponds to the statement of Nitrates Directive "(...) the amount of nitrogen present in the soil at the moment when the crop starts to use it to a significant degree (outstanding amounts at the end of winter)" (Council Directive 91/676/EE), and usually it is referred to as soil mineral nitrogen. This is a measureable indicator and numerous schemes for its determination and data interpretation are being developed but it is not discussed here.

The last parameter refers to nitrogen already uptaken by crops if such present in the field at the time of SNS assessment. Actually crop biomass and nitrogen content in it should be measured to assess this value. For practical use some schemes are developed to make this process more straightforward, e.g., determination of the crop density (number of shoots per $\mathrm{m}^{2}$ ) at the time of sampling taking into consideration that this value practically is necessary for winter crops - cereals or oilseed rape (Fertiliser Manual, 2010). Therefore it is possible to develop indicators showing the relationship between crop density (indication of biomass present in the field) and nitrogen content in $\mathrm{kg} \mathrm{ha}^{-1} \mathrm{~N}$, assuming that nitrogen content in crops at this early stage of development is more or less similar.

Estimation of nitrogen that will be released from mineralization of organic matter probably is the most crucial point to solve the problem. This value is changeable and differs from field to field. The content and quality of soil organic matter, soil physical, chemical and biological properties, soil tillage methods, climatic factors, cropping situation, post-harvest debris, etc. might influence this process and consequently the amount of mineral nitrogen released for plant uptake. Additionally, this source of nitrogen is the largest compared with others, e.g., nitrogen content in crop parts at the time of SNS assessment. Taking into account the amount of nitrogen which potentially is available for subsequent crop and to include it within the fertiliser management plan some feasible and practically useful methods should be proposed.

Several indicators are used to assess the nutrient performance on the crop yield. If soil is fertilised under current crop parameters, nutrient-uptake efficiency, i.e. proportion of a nutrient added to the soil that is absorbed by a plant growing in the soil (Barber, 1995) is used, or a similar value - nutrient use efficiency (NUE) (Dobermann, 2005; Benincasa et al., 2011; Janušauskaitè, 2013), or recovery of applied fertilisers (fertiliser recovery efficiency) (Greenwood et al., 1989). These concepts are similar but calculation methods and some parameters used for that might differ.

In routine tests there is no possibility to assess the actual recovery of fertilisers applied which might be possible only using radioactive tracers or similar technique. The use of tracers is advanced technology (Russel Boulding, Ginn, 2004) but its application is not possible outside from specially equipped research sites. Therefore for more practical situations so called "apparent" recovery of nutrients supplied by fertilisers is calculated. For example, apparent recovery of fertiliser nitrogen (nitrogen recovery efficiency) is calculated as the difference in nitrogen uptake between plots receiving nitrogen and plots without nitrogen and expressed as a proportion of the fertiliser nitrogen applied at the start of that particular time interval. The proportion of background nitrogen uptake in the fertilised treatment is calculated as the background nitrogen uptake (uptake in plot not receiving nitrogen) divided by the nitrogen uptake (in plot with nitrogen fertilisation), expressed as a percentage. It should be noted that the proportion of nitrogen taken up and that is actually derived from the applied fertiliser nitrogen cannot be confirmed and, hence, it is called "apparent" recovery of fertiliser nitrogen (Rao et al., 1992). Here the general assumption is - crops equally use the same amount of nitrogen despite the external sources (fertilisers) is available or not. Regardless of facts that more mobile forms of nutrients supplied by fertilisers could be used more efficiency if present compared with soil sources this approach of plant nutrient recovery calculation is widespread (Greenwood et al., 1989; Zemenchik, Albrecht, 2002; Brentrup, Palliere, 2010; Benincasa et al., 2011; Murphy et al., 2013).

The above mentioned considerations could be relevant also for assessment of soil nitrogen supply. To evaluate the net mineralizable soil nitrogen "apparent" values instead of measurable ones could be more useful. The extensive summary about possible assessment methods used for soil nitrogen supply was made by Ros (2011). The difficulties and complicity of analytical procedures regarding the quantification of the differences between laboratory and field experiments, the dependency of soil nitrogen supply on methodological and environmental issues, necessity to account for the numerous environmental factors controlling soil nitrogen supply was pointed out. As a result a holistic approach was proposed by the author, who considers spatial and temporal variability of both soil nitrogen supply and crop nitrogen demand, and this may provide a successful approach to improving fertiliser management at the farmscale (Ros, 2011). In other words, the only reliance of analytical methods for calculation of soil nitrogen supply, e.g., based on soil mineral nitrogen or soil mineralizable nitrogen, might result with over- or underestimates. These results should be combined together with other parametric values and experience based observations leading to the more accurate and realistic final conclusion. Of course, this is possible only having a good knowledge about the local farming conditions. 
Similar approach is supported also by other researchers (Schepers, Meisinger, 1994; Sanderson et al., 1999; Bélanger et al., 2000; Olfs et al., 2005; Zebarth et al., 2005). Soil nitrogen supply should be taken into consideration when making fertiliser nitrogen recommendations, but there is a lack of practical methods for routine estimation (analysing) of soil nitrogen supply under field conditions. As a result, there is limited information on the effect of soil properties, management factors and environmental conditions on soil nitrogen supply. Therefore soil nitrogen supply is commonly evaluated indirectly through crop response. For example, crop yield response to increasing rates of fertiliser nitrogen application (Sanderson et al., 1999; Bélanger et al., 2000) provides an estimate of the optimal fertiliser nitrogen rate, and can be used to estimate the relative magnitude of soil nitrogen supply.

The above mentioned approach was also proposed by us to make the fertiliser recommendations for field crops grown in Latvia (Fertiliser recommendations..., 2013). Depending on soil parameters commonly available from routine soil tests as well as cropping history data, approximate evaluation of soil nitrogen supply is performed. This amount is considered for fertilised rate planning avoiding excess nitrogen application by mineral fertilisers.

The purpose of this paper is to discuss the use of data covering some basic soil parameters available for every field as well as cropping history for assessment of nitrogen that will be released from mineralization of organic matter (soil humus plus post-harvest residues) necessary for compilation of fertiliser plans according to the requirements set up by Nitrates Directive. The main hypothesis is - the removal of nitrogen from plots not receiving nitrogen fertilisers and estimated apparent recovery of soil total organic nitrogen might be as indicators showing amount of nitrogen that will be released from mineralization of organic matter during vegetation.

\section{Materials and methods}

Data from field trials carried out in 2008-2012 was used. All together 72 field trials using the same layout were carried out in four locations of Latvia: Peterlauki $\left(56^{\circ} 32^{\prime}, 23^{\circ} 43^{\prime}\right)$, Priekuli $\left(57^{\circ} 18^{\prime}, 25^{\circ} 20^{\prime}\right)$, Vecauce $\left(56^{\circ} 28^{\prime}, 22^{\circ} 52^{\prime}\right)$ and Stende $\left(57^{\circ} 11^{\prime}, 22^{\circ} 33^{\prime}\right)$. The experiments were laid out in a randomised complete block design at each site with four replicates of each treatment. Plot size $-20-25 \mathrm{~m}^{2}$ (depending on the crop). In each trial 9 treatments were compared starting from non fertilised, fertilised with PK, as well as PK with increasing nitrogen rates: $30,60,90,120,150,180$ and $210 \mathrm{~kg} \mathrm{ha}^{-1} \mathrm{~N}$ (ammonium nitrate). Winter and spring wheat, rye, spring barley, winter and spring oilseed rape and potatoes were the crops grown in the experiments. The yield of main and by-product was accounted and total nitrogen (standard Kjeldahl procedure) was determined. Taking into consideration these values, nitrogen uptake was calculated (the main product plus by-product without postharvest residues).

Soils in the experimental sites were typical of Latvia's agricultural land: in Peterlauki-Endoprotocalcic
Chromic Stagnic Luvisol (Clayic, Cutanic, Hypereutric), silty clay loam/clay, in Priekuli - Endoeutric Endoluvic Stagnosol (Drainic, Loamic), fine sandy loam, in Vecauce - Calcaric Luvic Endostagnic Phaeozem (Protoanthric, Loamic), sandy loam/loamy sand, and in Stende - Eutric Stagnic Retisol (Cutanic, Drainic, Loamic), sandy clay loam (World Reference Base..., 2014). Every year before establishment of experiment, soil sampling was done and the following parameters were analysed for the depths of 0-20, 20-40 and 40-60 cm of topsoil: $\mathrm{pH}$ in $1 \mathrm{M} \mathrm{KCl}$ suspension, plant available phosphorous $\left(\mathrm{P}_{2} \mathrm{O}_{5}\right)$ and potassium $\left(\mathrm{K}_{2} \mathrm{O}\right)$ (Egner-Riehm method), exchangeable magnesium $(\mathrm{Mg})$ (calcium lactate extraction), organic carbon (Tyurin's method). For transformation of soil organic carbon data to soil organic matter (SOM), Van Bemmelen factor 1.724 was used. Soil density and field water capacity was also determined for every depth of soil (undisturbed sample saturation in $100 \mathrm{~mL}$ steel cylinders).

Soil organic nitrogen content was calculated according to the formula (Kārkliņš, 1995), developed for mineral soils $(\mathrm{SOM}<5 \%)$ :

$$
\mathrm{y}_{0}=\left(0.0762 \mathrm{x}^{3}-1.54 \mathrm{x}^{2}+10.7 \mathrm{x}-20.3\right) \times 0.01 \mathrm{SOM}
$$

where $\mathrm{y}_{0}$ is soil total organic nitrogen $\left(\mathrm{N}_{\mathrm{org}}\right), \%$, $\mathrm{x}$ - soil $\mathrm{pH} \mathrm{KCl,} \mathrm{SOM} \mathrm{-} \mathrm{soil} \mathrm{organic} \mathrm{matter,} \%$.

Using the data of bulk density, $\mathrm{N}_{\text {org }}$ content was transformed to $0-20$ and $0-40 \mathrm{~cm}$ soil layer and expressed as kg per ha $\mathrm{N}_{\text {org }}$. Apparent recovery of soil $\mathrm{N}_{\text {org }}$ (soil organic nitrogen recovery efficiency) was calculated as the difference in $\mathrm{N}$ uptake in the plots not receiving nitrogen fertilisers and $\mathrm{N}_{\text {org }}$ content $\left(\mathrm{kg} \mathrm{ha}^{-1}\right)$ in the soil within the depth of $0-20$ or $0-40 \mathrm{~cm}$ and expressed as a proportion of these two values.

Standard methods of descriptive statistics (correlation, variance, $t$-test) was used for data processing.

\section{Results and discussion}

Soils used for experiments were typical mineral soils with the following fertility parameters (Table 1). Conventional soil tillage and crop growing technology was used. As experiments were placed in different fields year by year, a range of soil properties are presented, which in average represent typical farming conditions of each region of Latvia.

Plant available phosphorous, potassium and magnesium contents in soils were in the range of medium to very high and therefore use of PK fertilisers excluding nitrogen application showed week response (Table 2). No manure or similar organic fertilisers were used directly under experimental crop to eliminate the residual fertility effect. In such a way it is possible to assume that nitrogen accumulated in the yield (main product, by-product) came from the soil resources, i.e. mineralization of soil organic matter and postharvest residues of precrop. Indirectly it might be referred to as soil nitrogen supply and this parameter combines two separate components given in formula 1 - net mineralizable nitrogen and soil mineral nitrogen which are derived from the first one. 
Table 1. Soil properties in experimental sites in Latvia

\begin{tabular}{cccccc}
\hline \multirow{2}{*}{ Location } & $\mathrm{pH} \mathrm{KCl}$ & $\begin{array}{c}\mathrm{SOM} \\
\%\end{array}$ & $\mathrm{P}_{2} \mathrm{O}_{5}$ & $\mathrm{~K}_{2} \mathrm{O}$ & $\mathrm{Mg}$ \\
\cline { 3 - 5 } & & & $0-20 \mathrm{~cm}$ & $\mathrm{mg} \mathrm{kg}^{-1}$ & \\
\hline Peterlauki & $6.6-7.2$ & $1.9-3.1$ & $102-240$ & $153-295$ & $497-984$ \\
Priekuli & $4.6-6.3$ & $1.9-3.1$ & $115-258$ & $93-232$ & $76-380$ \\
Vecauce & $6.3-7.3$ & $1.9-2.7$ & $133-391$ & $90-240$ & $136-551$ \\
Stende & $5.3-6.7$ & $1.9-2.7$ & $83-251$ & $126-189$ & $145-243$ \\
\hline & & & & $119-256$ & $528-2170$ \\
\hline Peterlauki & $6.6-7.4$ & $1.3-2.6$ & $50 \mathrm{~cm}-171$ & $59-194$ \\
Priekuli & $4.6-6.3$ & $1.5-2.3$ & $65-191$ & $102-260$ & $136-624$ \\
Vecauce & $6.4-7.2$ & $1.8-2.3$ & $122-374$ & $86-220$ & $178-234$ \\
Stende & $5.2-6.4$ & $0.9-2.3$ & $59-208$ & $101-178$ & \\
\hline
\end{tabular}

Table 2. Crop yield and nitrogen $(\mathrm{N})$ uptake by main and by-product

\begin{tabular}{lccccc}
\hline \multirow{2}{*}{ Crop } & Location & \multicolumn{2}{c}{ Yield (main product) t ha ${ }^{-1}$} & \multicolumn{2}{c}{ N uptake kg ha $^{-1}$} \\
\cline { 3 - 6 } & & unfertilised & PK only & unfertilised & PK only \\
\hline \multirow{2}{*}{ Winter wheat } & Peterlauki (8)* & 5.03 & 5.19 & 120.19 & 117.89 \\
& Stende (8) & 5.85 & 6.14 & 111.82 & 114.01 \\
\hline \multirow{2}{*}{ Spring wheat } & Peterlauki (5) & 3.85 & 4.01 & 94.40 & 96.72 \\
& Stende (3) & 3.32 & 3.47 & 91.02 & 85.31 \\
\hline \multirow{2}{*}{ Rye } & Priekuli (7) & 3.76 & 4.14 & 73.33 & 83.76 \\
& Stende (8) & 5.52 & 5.97 & 105.42 & 112.96 \\
\hline \multirow{2}{*}{ Spring barley } & Peterlauki (5) & 3.79 & 3.97 & 70.62 & 83.27 \\
& Priekuli (3) & 2.74 & 2.90 & 50.86 & 62.54 \\
\multirow{2}{*}{ Winter rape } & Stende (3) & 3.22 & 3.07 & 56.53 & 57.40 \\
\hline \multirow{2}{*}{ Spring rape } & Peterlauki (4) & 2.88 & 2.81 & 82.60 & 84.96 \\
& Vecauce (4) & 2.15 & 2.23 & 71.06 & 73.18 \\
\hline Potatoes & Peterlauki (3) & 1.36 & 1.40 & 61.03 & 59.74 \\
\hline \multirow{2}{*}{ Vin pary (3) } & 1.37 & 1.54 & 61.76 & 68.63 \\
\hline
\end{tabular}

* in parenthesis - number of trials

In average there was a small difference for nitrogen uptake in the plots receiving PK fertilisers or not - in average $91.06 \mathrm{~kg} \mathrm{ha}^{-1} \mathrm{~N}$ from unfertilised plot compared with $94.74 \mathrm{~kg} \mathrm{ha}^{-1} \mathrm{~N}$ from plot receiving PK fertilisers with standard deviation (SD) $33.69 \mathrm{~kg} \mathrm{ha}^{-1} \mathrm{~N}$ and coefficient of correlation $0.907(t=0.017)$. Therefore for future calculations the data from unfertilised plot ("pure zero") was used. As normally, there was quite notable fluctuation of obtained yield within the period of experiments and this was a factor for fluctuation of $\mathrm{N}$ uptake values year by year. Within the scope of this publication our task was not to characterize the impact of specifics of each vegetation period on productivity of crops, therefore only successive 5 year averages are given to illustrate the soil nitrogen utilisation (Table 3).

Table 3. Soil total organic nitrogen $\left(\mathrm{N}_{\mathrm{org}}\right)$ estimates and $\mathrm{N}$ apparent recovery

\begin{tabular}{lcccc}
\hline \multirow{2}{*}{ Crop } & \multicolumn{2}{c}{$\mathrm{N}_{\text {org }} \mathrm{kg} \mathrm{ha}^{-1}(0-20 \mathrm{~cm})$} & \multicolumn{2}{c}{ Apparent recovery $\% / \pm \mathrm{SD}$} \\
\cline { 2 - 5 } & minimal & maximal & $0-20 \mathrm{~cm}$ & $0-40 \mathrm{~cm}$ \\
\hline Winter wheat & 2477 & 4785 & $3.4 \pm 0.95$ & $1.9 \pm 0.53$ \\
Spring wheat & 2785 & 4171 & $2.6 \pm 0.63$ & $1.4 \pm 0.33$ \\
Rye & 2067 & 3216 & $3.3 \pm 1.38$ & $1.7 \pm 0.72$ \\
Spring barley & 2509 & 4380 & $1.8 \pm 0.68$ & $1.0 \pm 0.33$ \\
Winter rape & 2968 & 4462 & $2.3 \pm 0.85$ & $1.2 \pm 0.46$ \\
Spring rape & 2797 & 4621 & $1.8 \pm 0.44$ & $1.0 \pm 0.24$ \\
Potatoes & 2119 & 3566 & $3.8 \pm 0.69$ & $2.2 \pm 0.40$ \\
\hline \multicolumn{1}{c}{ In average } & 2067 & 4785 & $2.86 \pm 1.169$ & $1.56 \pm 0.646$ \\
\multicolumn{1}{c}{ LSD $_{05}$} & - & - & 0.279 & 0.154 \\
\hline
\end{tabular}


For each experiment soil sampling was done separately in two depths $-0-20$ and $20-40 \mathrm{~cm}$. Obviously, crops are utilizing nitrogen from all zones of distribution. Practically this zone could be named as a plough layer (tillage layer) which in our conditions is somewhere between 25 to $30 \mathrm{~cm}$ from the soil surface. On the other hand, soil sampling for routine tests in commercial farms is performed in the depth of $0-20 \mathrm{~cm}$ taking into consideration that for majority of field crops upper topsoil is sufficiently homogeneous due to the annual tillage operations. For this reason, the data presented in Table 3 shows the amount of total organic nitrogen in the soil within the depth of $0-20 \mathrm{~cm}$ (sampling depth) but apparent recovery is calculated in two ways - based on soil analysis done for 0-20 cm layer; and based on soil analysis done for $0-20$ and $20-40 \mathrm{~cm}$ layers and afterwards summing of obtained results.

The highest soil nitrogen apparent recovery was obtained for potatoes. Probably intensive soil tillage normally used for this crop tends to stimulate the mineralization of soil organic matter and nitrogen release. For other crops strong tendency for winter crops to utilize soil nitrogen more efficiently compared with spring ones was obtained. There was strong correlation $(r=0.980$, $P \leq 0.01)$ between apparent recovery values if they were calculated only based on $0-20 \mathrm{~cm}$ soil layer or based on $0-40 \mathrm{~cm}$. Therefore it is possible to make calculations only for topsoil data which is available from routine soil tests. There was also strong correlation $(r=0.853, P \leq$ 0.01 ) between nitrogen uptake by crops and nitrogen apparent recovery, but weak correlation $(r=-0.366)$

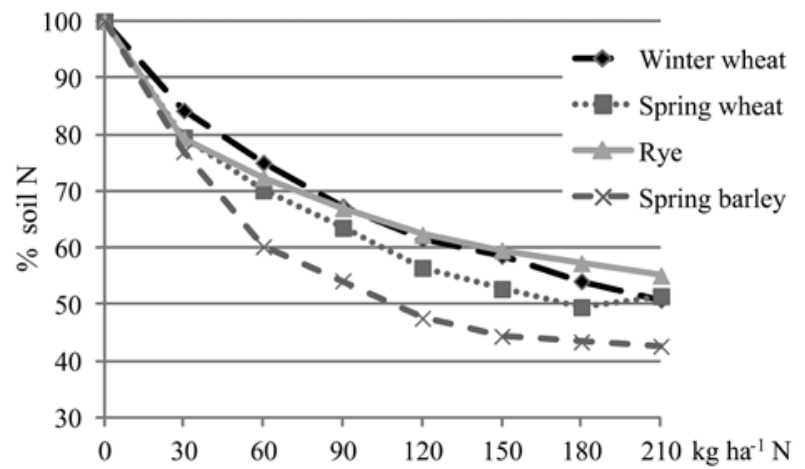

between organic nitrogen in soil and nitrogen apparent recovery, as well as between $\mathrm{N}_{\text {org }}$ in soil and $\mathrm{N}$ uptake by crop $(r=0.120)$. Therefore soil conditions (SOM content or $\mathrm{N}_{\text {org }}$ in soil) were not the main parameters influencing nitrogen uptake by crops. The main factor was obtained yield, which in average was reasonable for non-fertilised crops in Latvia (Table 2) and $\mathrm{N}$ uptake data specifies its value.

Following the general assumption that crops equally use the soil nitrogen pool, regardless of whether nitrogen containing fertilisers are used or not, some calculations were made (Fig.). As for all crops, the same rates of nitrogen containing fertilisers (ammonium nitrate) were used, recovery of applied nitrogen was calculated keeping in mind that in control plot ("pure zero") all nitrogen comes from soil resources, but in the plots receiving nitrogen fertilisers, partly from the soil and partly from the fertilisers applied. For all crops, there was a clear tendency for decreasing of soil nitrogen share in the total removal of nitrogen by obtained yield (main product + by-product). Winter cereals (wheat, rye) tend to keep somewhat higher share of soil nitrogen supply compared with spring cereals, but even in the situation when high nitrogen application rates were used $\left(180-210 \mathrm{~kg} \mathrm{ha}^{-1} \mathrm{~N}\right)$ some $40 \%$ to $50 \%$ of nitrogen found in the yield could be regarded as soil supplied. This is an illustrative approach because in the framework of the experiment it was not possible to investigate the separate compartments of recovery factors, e.g., to distinguish between soil derived nitrogen uptake and fertiliser induced in the situations when both nitrogen pools are available.

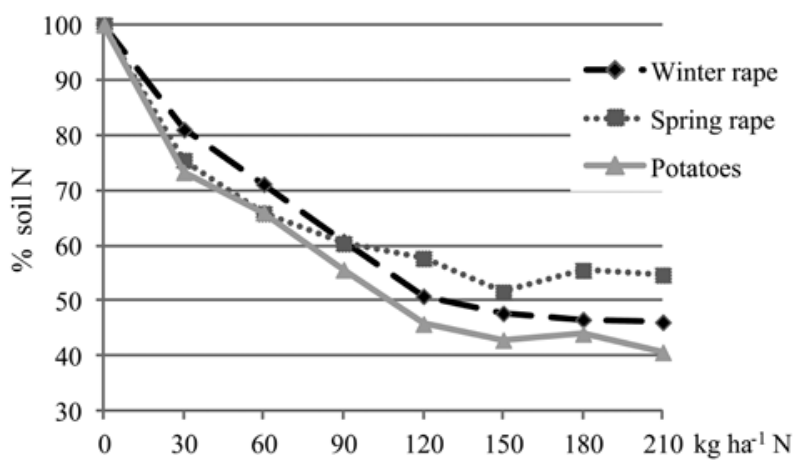

Note. The number of trials is provided in Table 2.

Figure. Share of soil nitrogen $(\mathrm{N})$ in the total removal of nitrogen by yield depending on nitrogen applied with fertilisers

Our data has good agreement with experimental results obtained in Vokè Branch of Lithuanian Institute of Agriculture carried out in 1987-1992 on a soddypodzolic sandy loam soil (Tripolskaja, Panamariovienè, 1997). In the experiments using ${ }^{15} \mathrm{~N}$-labelled ammonium nitrate, $32.3-41.0 \%$ of nitrogen applied was uptaken by barley. From the total nitrogen accumulated in barley yield $15-40 \%$ came from fertilisers but $60-85 \%$ - from the soil. About one third (24.5-38.5\%) of fertiliser nitrogen remained in soil due to the immobilisation by soil organisms but in the next year $1.2-5.0 \%$ (from nitrogen applied) becomes available again through remineralization. Leaching losses of nitrogen from mineral fertilisers were negligible - only $2.2-4.4 \%$ from the amount applied (Tripolskaja, Panamariovienè, 1995).

In the United Kingdom, fertiliser nitrogen uptake by winter wheat was measured using ${ }^{15} \mathrm{~N}$-labelled calcium nitrate applied at $80 \mathrm{~kg} \mathrm{ha}^{-1} \mathrm{~N}$ rate. The recovery of fertiliser nitrogen by crops at the time of harvest was in the range $60-67 \%$ of that applied in the first year and $0.5-0.7 \%$ in the second year. The calculated apparent recovery of fertiliser nitrogen was somewhat greater 
and ranged from $77-111 \%$ of that applied. Estimates of the contribution of non-fertiliser nitrogen to the crop by means of ${ }^{15} \mathrm{~N}$ analysis suggested that if this nitrogen had been utilised with the same efficiency as that of fertiliser nitrogen, about $120 \mathrm{~kg} \mathrm{ha}^{-1} \mathrm{~N}$ was available to the plants (Rodney et al., 1980). Similar experiments in Denmark showed nitrogen recovery by winter wheat and spring barley approximately 59-64\% from supplied by ${ }^{15} \mathrm{~N}$-labelled ammonium nitrate (Thomsen, Christensen, 2007). In Northern France, ${ }^{15} \mathrm{~N}$-labelled fertiliser was applied on a silt loam soil at the rate of $100 \mathrm{~kg} \mathrm{ha}^{-1} \mathrm{~N}$ for wheat after pea and $120 \mathrm{~kg} \mathrm{ha}^{-1} \mathrm{~N}$ for wheat after maize. ${ }^{15} \mathrm{~N}$ recovery by plants (above ground biomass plus roots) amounted to $59-63 \%$ at flowering and harvest time (Giacomini et al., 2010). To some extent, these suggestions are applicable also to our research findings showing that only part of nitrogen requirements plants cover from fertilisers applied. The rest is coming from soil resources even if the fertiliser rates are substantial. It is in agreement with most published results obtained in the soil and climate conditions similar to ours. The optimal nitrogen rate for specific crop is variable and dependent on many factors and is not discussed here. But the illustration given in Figure shows the necessity to take into account soil nitrogen pool as well, even when high nitrogen application rates are planned to use for achieving high yield goals.

Some other methods also are proposed for routine application. For example, quick-tests for analysis of crop sap to assess crop nitrogen sufficiency and afterwards to make the decision on fertiliser requirement and even dosage. However, some authors point out that those plant-based tests can be used only to assess crop nitrogen sufficiency at the moment of measurement but these approaches do not provide direct estimates of soil nitrogen supply (Porter, Sisson, 1991; Minotti et al., 1994; Olfs et al., 2005).

Burns (2006) examined the crop nitrogen uptake efficiency in detail, concluding that the crop nitrogen uptake from the soil is a function of two recovery factors, one for the fertiliser nitrogen and one for the soil nitrogen. The two recovery factors are required because soil nitrogen and fertiliser nitrogen may be differently available in time and space. However, the author concluded that in most cases the two recovery factors can be considered nearly equivalent; therefore the uptake efficiency of fertiliser nitrogen (apparent nitrogen recovery) can be estimated on the basis of the nitrogen uptake of the unfertilised control as proposed by other authors (Greenwood et al., 1989; Zemenchik, Albrecht, 2002; Benincasa et al., 2011; Murphy et al., 2013).

\section{Conclusions}

1. Soil nitrogen supply is an important factor which should be taken into account for fertiliser planning, especially for farms operating in the so-called vulnerable zones. As acceptable direct measurement methods which could be successfully used on the farm level are lacking, an indirect one is proposed. Nitrogen supply value for mineral soils (soil organic matter $<5 \%$ ) could be calculated from the soil organic matter content and using coefficients of nitrogen apparent recovery by selected crops.

2. There was strong correlation $(r=0.980$, $P \leq 0.01)$ between apparent recovery values if they were calculated only based on $0-20 \mathrm{~cm}$ soil layer or based on $0-40 \mathrm{~cm}$. Therefore it is possible to make calculations only for topsoil data which is available from routine soil tests.

3. Winter cereals (wheat, rye) tended to keep higher share of soil nitrogen supply compared with spring cereals, but even in the situation when high nitrogen application rates were used $\left(180-210 \mathrm{~kg} \mathrm{ha}^{-1} \mathrm{~N}\right)$ some $40 \%$ to $50 \%$ of nitrogen found in the yield could be regarded as soil supplied.

\section{Acknowledgements}

The research was funded by the Latvia State Research Programme "Sustainable use of local resources (Earth, food, and transport)-new products and technologies (NatRes)" (2010-2014), Project No. 3 "Sustainable use of local agricultural resources for development of high nutritive value food products (Food)" and Project No. 1 (SOIL) "Sustainable use of soil resources and abatement of fertilisation risks" related to the Latvia State Research Program AgroBioRes (2014-2017).

Received 09082014

Accepted 22122014

\section{References}

Barber S. A. 1995. Soil nutrient bioavailability: a mechanic approach ( $2^{\text {nd }}$ ed.). New York, USA, $414 \mathrm{p}$.

Bélanger G., Walsh J. R., Richards J. E., Milburn P. H., Ziadi N. 2000. Yield response of two potato cultivars to supplemental irrigation and $\mathrm{N}$ fertilization in New Brunswick. American Journal of Potatoes Research, 77: 11-21 http://dx.doi.org/10.1007/BF02853657

Benincasa P., Guiducci M., Tei F. 2011. The nitrogen use efficiency: meaning and sources of variation - case studies on three vegetable crops in Central Italy. HortTehnology, 21 (3): 266-273

Brentrup F., Palliere C. 2010. Nitrogen use efficiency as an agro-environmental indicator. OECD workshop Agrienvironmental indicators: lessons learned and future directions. Leysin, Switzerland, p. 1-9. <http://www.oecd. org/tad/sustainable-agriculture/44810433.pdf $>$ [accessed 0408 2014]

Burns I. G. 2006. Assessing N fertiliser requirements and the reliability of different recommendation systems. Acta Horticulturae, 700: 35-48

Council Directive 91/676/EE of 12 December 1991 concerning the protection of waters against pollution caused by nitrates from agricultural sources as amended by Regulations 1882/2003/EC and 1137/2008/EC. <http://rod.eionet. europa.eu/instruments/257> [accessed 0408 2014]

Directive 2000/60/EC of the European Parliament and of the Council of 23 October 2000 establishing a framework for Community action in the field of water policy. 
$<$ http://eur-lex.europa.eu/legal-content/EN/TXT/ $\mathrm{PDF} /$ ?uri=CELEX:02000L0060-20140101\&from=EN> [accessed 2211 2014]

DobermannA.R.2005.Nitrogenuseefficiency-stateoftheart.IFA International Workshop on Enhanced-Efficiency Fertilizers. Frankfurt, Germany, p. 1-17<http://digitalcommons. unl.edu/cgi/viewcontent.cgi\%3Farticle\%3D1319\% 26context\%3Dagronomyfacpub $>$ [accessed 0408 2014]

Fertiliser Manual. 2010 ( $8^{\text {th }}$ ed.). Department for Environment, Food and Rural Affairs (Defra), UK, 249 p.

Fertiliser recommendations for agricultural crops. 2013 Karklins A., Ruza A. (eds.). Jelgava, Latvia, 55 p. (in Latvian)

Giacomini S. J., Machet J. M., Boizard H., Recous S. 2010. Dynamics and recovery of fertilizer ${ }^{15} \mathrm{~N}$ in soil and winter wheat crop under minimum versus conventional tillage. Soil and Tillage Research, 108 (1-2): 51-58 http://dx.doi.org/10.1016/j.still.2010.03.005

Greenwood D. J., Kubo K., Burns I. G., Draycott A. 1989. Apparent recovery of fertilizer $\mathrm{N}$ by vegetable crops. Soil Science and Plant Nutrition, 35 (3): 367-381 http://dx.doi.org/10.1080/00380768.1989.10434770

Hofman G., Ossemerct C., Ide G., Van Ruymbeke M. 1985. Nitrogen supply from some soil types with various organic-matter treatments. Fundamental, Ecological and Agricultural Aspects of Nitrogen Metabolism in Higher Plants: Developments in Plant and Soil Sciences, 19: 433-437

Janušauskaitė D. 2013. Spring triticale yield formation and nitrogen use efficiency as affected by nitrogen rate and its splitting. Zemdirbyste-Agriculture, 100 (4): 383-392 http://dx.doi.org/10.13080/z-a.2013.100.049

Kārkliņš A. 1995. Comparison of some soil total nitrogen determination methods. Proceedings of the Latvia University of Agriculture, 1 (278): 1-7

Minotti P. L., Halseth D. E., Sieczka J. B. 1994. Field chlorophyll measurements to assess the nitrogen status of potato varieties. HortScience, 29: 1497-1500

Murphy P. N. C., O'Connell K., Watson S., Watson C. J., Humphreys J. 2013. Seasonality of nitrogen uptake, apparent recovery of fertilizer nitrogen and background nitrogen supply in two Irish grassland soils. Irish Journal of Agricultural and Food Research, 52: 17-38

Olfs H. W., Blankenau K., Brentrup F., Jasper J., Link A., Lammel J. 2005. Soil- and plant-based nitrogen-fertilizer recommendations in arable farming. Journal of Plant Nutrition and Soil Science, 168 (4): 414-431 http://dx.doi.org/10.1002/jpln.200520526

Porter G. A., Sisson J. A. 1991. Petiole nitrate content of Mainegrown Russet Burbank and Shepody potatoes in response to varying nitrogen rate. American Potato Journal, 68: 493-505 http://dx.doi.org/10.1007/BF02853766

Rao A. C. S., Smith J. L., Parr J. F., Papendick R. I. 1992. Considerations in estimating nitrogen recovery efficiency by the difference and isotopic dilution methods. Fertilizer Research, 33: 209-217 http://dx.doi.org/10.1007/BF01050876

Rodney J., Dowdell R. J., Crees R. 1980. The uptake of ${ }^{15} \mathrm{~N}$-labelled fertiliser by winter wheat and its immobilisation in a clay soil after direct drilling or ploughing. Journal of the Science of Food and Agriculture, 31: 992-996 http://dx.doi.org/10.1002/jsfa.2740311004
Ros G. H. 2011. Predicting soil nitrogen supply relevance of extractable soil organic matter fractions: thesis for the degree of doctor at Wageningen University, $248 \mathrm{p}$.

Russel Boulding J., Ginn J. S. 2004. Practical handbook of soil, vadose zone and ground water contamination: assessment, prevention and remediation ( $\left.2^{\text {nd }} e d.\right), 691 \mathrm{p}$.

Sanderson J. B., MacLeod J. A., Kimpinski J. 1999. Glyphosate application and timing of tillage of red clover affects potato response to $\mathrm{N}$, soil $\mathrm{N}$ profile, and root and soil nematodes. Canadian Journal of Soil Science, 79: 65-72 http://dx.doi.org/10.4141/S98-028

Schepers J. S., Meisinger J. J. 1994. Field indicators of nitrogen mineralization. Soil testing: prospects for improving nutrient recommendations. SSSA Special Publication 40, Madison, USA, p. 31-47

Sharifi M., Zebarth B. J., Burton D. L., Grant C. A., Porter G. A., Cooper J. M., Leclerc Y., Moreau G., Arsenault W. J. 2007. Evaluation of laboratory-based measures of soil mineral nitrogen and potentially mineralizable nitrogen as predictors of field-based indices of soil nitrogen supply in potato production. Plant and Soil, 301 (1-2): 203-214 http://dx.doi.org/10.1007/s11104-007-9438-7

Thomsen I. K., Christensen B. T. 2007. Fertilizer ${ }^{15} \mathrm{~N}$ recovery in cereal crops and soil under shallow tillage. Soil and Tillage Research, 97 (1): 117-121 http://dx.doi.org/10.1016/j.still.2007.09.004

Tripolskaja L., Panamariovienè A. 1995. Nutrient migration in the soddy podzolic sandy loams under fodder crop rotation. Zemdirbyste-Agriculture, 50: 76-84 (in Lithuanian)

Tripolskaja L., Panamariovienè A. 1997. Establishement of fertilizer nitrogen utilization in barley stand by the method of isotopes. Zemdirbyste-Agriculture, 57: 16-23 (in Lithuanian)

World Reference Base for Soil Resources. 2014. International soil classification system for naming soils and creating legends for soil maps. World Soil Resources Reports No. 106. FAO, Rome, 181 p.

Zebarth B. J., Leclerc Y., Moreau G., Sanderson J. B., Arsenault W. J., Botha E. J., Wang-Pruski G. 2005. Estimation of soil nitrogen supply in potato fields using a plant bioassay approach. Canadian Journal of Soil Science, 85: $377-386$ http://dx.doi.org/10.4141/S04-054

Zemenchik R. A., Albrecht K. A. 2002. Nitrogen use efficiency and apparent nitrogen recovery of Kentucky bluegrass, smooth bromegrass, and orchardgrass. Agronomy Journal, 94 (3): 421-428 http://dx.doi.org/10.2134/agronj2002.4210 
ISSN 1392-3196 / e-ISSN 2335-8947

Zemdirbyste-Agriculture, vol. 102, No. 2 (2015), p. 133-140

DOI 10.13080/z-a.2015.102.017

\title{
Organinio azoto panaudojimo efektyvumas kaip dirvožemio aprūpinimo azotu rodiklis
}

\author{
A. Karklins, A. Ruza \\ Latvijos žemès ūkio universitetas
}

\section{Santrauka}

Nitratų direktyva prieš priimant sprendimą dèl mineralinių trą̌̌u naudojimo reikalauja atsižvelgti i visus galimus augalams pasiekiamus azoto šaltinius. Dirvožemis yra vienas iš azoto šaltinių, tačiau sunku kiekybiškai ịvertinti, kiek jis galètų atpalaiduoti azoto augalų ịsisavinama forma ir kiek jo būtụ panaudota formuojant derliụ. Cheminiai ir biologiniai metodai atliekant laboratorinius ir lauko bandymus ne visuomet yra veiksmingi ar praktiškai pritaikomi ūkio sąlygomis. Todèl siūlomas netiesioginis azoto kiekio dirvožemyje ịvertinimo metodas, kuris leistų panaudoti ūkiuose turimus laukų tyrimų duomenis. Pirmiausia reikia ivertinti sumini azoto kiekị dirvožemyje pagal organinės medžiagos kiekio ir pH rodiklius. Po to, remiantis lauko bandymų rezultatais, ịvertinti dirvožemio organinio azoto panaudojimo efektyvumo veiksnius. Tai buvo padaryta žieminiams rugiams ir kviečiams, vasariniams kviečiams ir miežiams, žieminiams ir vasariniams rapsams, taip pat bulvèms, ir jie remiasi 72 lauko bandymų, atliktų mineraliniuose dirvožemiuose Latvijoje penkerių metụ laikotarpiu (2008-2012), duomenimis. Buvo gauti tokie vidutiniai dirvožemio organinio azoto panaudojimo efektyvumo rodikliai: žieminiams javams $-3,3-3,4 \%$, žieminiams rapsams $-2,3 \%$, vasariniams javams ir rapsams $-1,8-2,6 \%$, bulvėms $-3,8 \%$, apskaičiuoti iš suminio organinio azoto kiekio dirvožemio $0-20 \mathrm{~cm}$ sluoksnyje. Nustatyta stipri koreliacija $(r=0,980, P \leq 0,01)$ tarp azoto efektyvumo verčių, jeigu jos buvo apskaičiuotos remiantis tiktai dirvožemio $0-20$ arba $0-40 \mathrm{~cm}$ sluoksnio duomenimis. Taigi, duomenis galima apskaičiuoti tik iš dirvožemio viršutinio sluoksnio, kurie gaunami atliekant dirvožemio rutininius tyrimus.

Reikšminiai žodžiai: dirvožemio aprūpinimas azotu, dirvožemio mineralinis azotas, dirvožemio organinė medžiaga, tręšimo rekomendacijos. 